\title{
PENGARUH LATIHAN SENAM AEROBIK TERHADAP INDEKS MASSA TUBUH MEMBER MUSLIMAH FITNESS CENTER
}

\author{
Rizki Ramadhani \\ S1 PG Pendidikan Anak Usia Dini,Universitas Negeri Medan \\ rizkiramram@unimed.ac.id
}

\begin{abstract}
The problem of this research is how the influence of low impact aerobic exercises and a mixed impact on the body mass index. This research was conducted in Muslim Fitness Center Padang. The sample are the members of the Muslimah Fitness Center with a total of 24 people. The method used in this research is quasi experiment. The instrument used in this study is the weight and height assessment sheets. They were calculated using the formula of the body mass index which is weight divided by height squared. It is classified by the threshold of body mass index in Indonesia. Then, the data was analyzed by using t-test. Data collection was performed twice which are before the exercise program given (pre-test) and after the exercise program which was at 16 meeting (post-test). Based on the results, the overall of body mass index reduction was obtained by the Muslimah members of Fitness Center Padang. In the group of low impact aerobic exercises, the average body mass index of the member on the initial test was 26.56 and the final test 25.69, In the group of mixed impact exercise, the average body mass index of member in its pre test was 28,25 and post test was 27.5. With these differences of two exercise groups, it is found that the average difference of body mass index mixed impact exercise group > low impact exercise group. It means a mixed impact aerobic exercise is not better than low impact aerobic exercises in decreasing body mass index.
\end{abstract}

Keywords $\quad$ : Aerobics, Bmi, Dance, Low, Mix

\begin{abstract}
ABSTRAK
Rumusan masalah dalam penelitian ini adalah bagaimana pengaruh latihan aerobik low impact dan mixed impact terhadap indeks massa tubuh. Penelitian ini dilakukan di Muslim Fitness Center Kota Padang. Sampel penelitian adalah anggota Muslimah Fitness Center yang berjumlah 24 orang. Metode yang digunakan dalam penelitian ini adalah eksperimen semu. Instrumen yang digunakan dalam penelitian ini adalah lembar penilaian berat dan tinggi badan. Dihitung dengan menggunakan rumus indeks massa tubuh yaitu berat badan $(\mathrm{kg})$ dibagi tinggi badan $(\mathrm{m})$ kuadrat. Ini diklasifikasikan berdasarkan ambang indeks massa tubuh di Indonesia. Kemudian data dianalisis dengan menggunakan uji-t. Pengumpulan data dilakukan sebanyak dua kali yaitu sebelum program latihan diberikan (pre-test) dan setelah program latihan yaitu pada 16 pertemuan (post-test). Berdasarkan hasil penelitian didapatkan penurunan indeks massa tubuh secara keseluruhan oleh Muslimah anggota Fitness Center Padang. Pada kelompok senam aerobik impak rendah rata-rata indeks massa tubuh anggota pada tes awal (pre-test) adalah 26,56 dan tes akhir (post test) 25,69. Pada kelompok latihan mixed impact rata-rata indeks massa tubuh anggota pada pre test adalah 28,25 dan post test adalah 27,5. Dengan perbedaan kedua kelompok olah raga tersebut maka didapatkan perbedaan rata-rata kelompok senam mixed impact > kelompok senam low impact artinya senam aerobik mixed impact tidak lebih baik dibandingkan latihan aerobik low impact dalam menurunkan indeks massa tubuh.
\end{abstract}

Kata kunci $\quad$ : Aerobic, Campuran, IMT, Rendah Dan Senam 


\section{PENDAHULUAN}

Kegemukan adalah kelebihan berat badan dimana terjadi penumpukan lemak di atas ambang normal. Penumpukan kadar lemak diakibatkan asupan makanan yang masuk tidak seimbang dengan energi yang terpakai. Asupan makanan yang mengandung karbohidrat dan lemak yang tidak terpakai akan disimpan sebagai cadangan makanan di jaringan adipose, jika tubuh memerlukan energi maka cadangan makanan yang tersimpan di jaringan adipose akan terurai dan diproses menjadi suatu energi (Achmad dalam Novitasari 2013).

Selain itu pada era globalisasi ini orang lebih memilih kenyamanan dan kemudahan. Hal ini dapat dilihat dengan berkembangnya tempat makan cepat saji dengan suguhan makanan yang tidak disadari berbahaya untuk tubuh yang mengakibatkan tubuh tidak ideal. Dengan keberadaan tempat makan cepat saji tersebut yang juga menyediakan layanan pesan antar memudahkan para pembeli untuk tidak perlu mendatangi tempat makan tersebut namun hanya dengan menggunakan telepon. Dengan ini jadwal makan masyarakat juga berubah dan tidak terkontrol.

Hasil Riset Kesehatan Dasar pada tahun 2013 prevalensi obesitas perempuan dewasa (>18 tahun) 32,9 persen, naik 18,1 persen dari tahun 2007 $(13,9 \%)$ dan 17,5 persen dari tahun 2010 $(15,5 \%)$. Hasil riset ini menunjukkan peningkatan obesitas perempuan dewasa dalam 2 riset terakhir dalam laporan badan penelitian dan pengembangan kesehatan kementerian kesehatan Republik Indonesia. Kawachi dalam Nourshahi (2009) menyatakan obesitas dan kelebihan berat badan berhubungan dengan berbagai macam penyakit serius, seperti 2 tipe diabetes, hipertensi, penyakit jantung koroner.

Saat ini, untuk menyamakan konsep atau defenisi kegemukan secara
Internasional indeks massa tubuh (IMT) telah diterima sebagai alat untuk mengidentifikasi kelebihan berat badan dan obesitas. (Hill dalam Sara, 2009). Indeks Massa Tubuh (IMT) merupakan cara termudah untuk memperkirakan obesitas serta berkorelasi tinggi dengan massa lemak tubuh. Penggunaan IMT praktis dan dengan cepat diperoleh gambaran tentang keadaan komposisi tubuh seseorang (Lutan, 2002). Ini merupakan pengukuran indeks massa tubuh paling baik untuk populasi dewasa karena memiliki tingkat kesalahan paling kecil dan mudah menghitungnya. Penggunaan IMT hanya berlaku untuk orang dewasa di atas 18 tahun (Supariasa, 60:2001).

Indeks Massa Tubuh (IMT) adalah nilai yang diambil dari perhitungan antara berat badan dan tinggi badan seseorang. IMT dipercayai dapat menjadi indikator atau menggambarkan kadar adipositas dalam tubuh seseorang.

Rumus perhitungan IMT adalah sebagai berikut:

$$
\begin{gathered}
\text { IMT }=\frac{\text { Berat Badan }(\mathrm{Kg})}{\text { Tinggi badan } \times \text { Tinggi Badan }(\mathrm{m})} \\
\text { Sumber }: \text { DepKes } 1994 \text { dalam Supariasa } 2001
\end{gathered}
$$

Hubungan antara lemak tubuh dan IMT ditentukan oleh bentuk dan proporsi tubuh, sehingga IMT belum tentu memberikan gambaran kegemukan yang sama bagi semua populasi. Orang Asia mempunyai deposit lemak tubuh lebih tinggi pada IMT lebih rendah dibandingkan ras Kaukasia.

Untuk kepentingan Indonesia, batas ambang dimodifikasi lagi berdasarkan pengalaman klinis dan hasil penelitian di beberapa negara berkembang. Akhirnya diambil ambang batas IMT untuk Indonesia sebagai berikut : 
Tabel 1.Kategori ambang batas IMT di Indonesia

\begin{tabular}{ccc}
\hline & \multicolumn{1}{c}{ Kategori } & IMT \\
\hline Kurus & Kekurangan berat badan & $<17$ \\
& tingkat berat & \\
& Kekurangan berat badan & $17,0-$ \\
& tingkat ringan & 18,5 \\
Normal & & $18,5-$ \\
& & 25,0 \\
Gemuk & Kelebihan berat badan & $>25,0-$ \\
& tingkat ringan & 27 \\
& Kelebihan berat badan & $>27,0$ \\
tingkat berat &
\end{tabular}

Mengantisipasi kegemukan tersebut, saat ini banyak masyarakat yang mengikuti klub kebugaran yang menawarkan berbagai macam program. Kegiatan berolahraga di klub kebugaran sekarang ini bukan lagi menjadi suatu kebutuhan melainkan juga menjadi suatu gaya hidup tersendiri bagi masyarakat Indonesia. Berolahraga di klub kebugaran dapat menjadi gaya hidup karena selain mendapatkan tubuh yang sehat, setiap orang juga dapat memiliki penampilan yang menarik serta di klub kebugaran menawarkan berbagai macam jenis olahraga yang dapat menurunkan berat badan salah satunya adalah senam aerobik.

Senam aerobik dipilih menjadi salah satu solusi untuk masalah kelebihan berat badan karena senam aerobik termasuk kedalam olahraga dengan sistem energi aerobik. Sistem energi aerobik adalah suatu kegiatan fisik yang membutuhkan energi oksigen dalam melakukan aktivitas tubuh. Sistem aerobik ini selain menggunakan glukosa juga menggunakan nutrisi lain yaitu lemak dan protein. Sistem energi ini akan terpakai pada intensitas kerja yang rendah dan dalam waktu yang lama.

Berdasarkan penelitian yang telah dilakukan oleh Radmila Kostic (2006) diketahui bahwa senam aerobik secara teratur 3 kali dalam seminggu, dilakukan minimal 40 Menit setiap kali latihan dan selama 12 minggu dengan intensitas $60 \%$ $80 \%$ dapat menurunkan berat badan. Sedangkan penelitian lain yang dilakukan oleh Fatma Arslan (2011) diketahui bahwa dengan melakukan senam aerobik secara teratur yang dilakukan selama 8 minggu dengan durasi setiap latihan minimal 30 menit memberikan pengaruh yang signifikan terhadap penurunan berat badan wanita berusia menengah.

Namun pada data di lapangan yang saya peroleh ketika observasi di Muslimah Fitness Center Kota Padang yang memiliki 25 member aktif dari berbagai usia walaupun didominasi oleh wanita berusia subur masih banyak terdapat member senam aerobik Muslimah Fitness Center yang mengalami kegemukan. Padahal para member tersebut telah mengikuti kelas aerobik bertahun-tahun lamanya dan tidak mendapatkan berat badan normal. Tujuan member melakukan latihan di sanggar tersebut bervariasi, ada yang ingin menurunkan berat badan, bersenang-senang, meningkatkan kebugaran jasmani dan hanya ikut-ikutan.

Menurut Apri Agus (2012:5) senam aerobik adalah aktivitas (gerak) yang dilakukan oleh perorangan maupun kelompok orang secara berirama, menggunakan otot-otot besar, serta aktivitas dilakukan dnegan menggunakan oksigen yang bertujuan untuk peningkatan dan pemeliharaan kebugaran. Pitnawati (2004:8) senam aerobik adalah latihan yang dilakukan untuk membakar lemak sambil memperbaiki kekencangan otot yang dipimpin oleh pelatih/instruktur berpengalaman secara bersama-sama dengan diiringi musik Senam aerobik memiliki tujuan yaitu meningkatkan kemampuan jantung dan paru dan pembentukan tubuh (Marta Dinata, 2004:5). Kemudian Brick (2002) menyatakan gerakan-gerakan senam aerobik menyelaraskan bagian atas tubuh dan bagian bawah tubuh secara bersamaan kemudian akan mendapatkan lebih banyak kegembiraan dan lebih bersemangat ketika menggabungkan gerakan dasar. 
Seperti bentuk-bentuk lain dari latihan aerobik, senam aerobik dilakukan dalam tingkat target jantung antara $60 \%$ dan $70 \%$ dari denyut jantung maksimal (MHR) telah menunjukkan manfaat kardiovaskular dan metabolisme seperti peningkatan konsumsi maksimal oksigen $\left(\mathrm{VO}_{2} \max \right)$, meningkatkan kapasitas daya tahan aerobik, dan peningkatan produksi energi melalui sistem respirasi mitokondria (Schiffer, 2009). Lebih lanjut Sumosardjono (1996) mengatakan keuntungan pada badan kita dengan melakukan latihan-latihan senam aerobik terutama pada jantung dan paru.

Berdasarkan penjelasan-penjelasan tersebut dapat disimpulkan senam aerobik adalah serangkaian gerak yang menggunakan otot-otot besar yang dipilih, diciptakan disusun secara sistematis dan dilaksanakan sendiri atau berkelompok dengan diiringi musik sehingga melahirkan keharmonisan.

Seiring dengan perkembangan senam aerobik para pakar dan pencipta senam aerobik semakin berkembang. Pada dasarnya gerakan gerakan senam aerobik diambil dari gerakan tari-tarian, seni, budaya, olahraga atau pun gerakan seharihari. Senam aerobik tanpa alat dibagi menjadi tiga bagian yaitu menjadi low impact aeobic (benturan rendah), high impact aerobic (benturan tinggi), mixed impact aerobic (gabungan benturan rendah dan sedang) dan non impact aerobic (aerobik tanpa benturan).

Brick (2002:31) mengatakan "Gerakan-gerakan aerobik low impact membutuhkan sebuah kaki yang selalu berada di lantai setiap waktu". Senam Low Impact Aerobic merupakan gerakan senam yang dilakukan dengan irama Low (rendah) yaitu bentuk gerakannya lebih lambat, dengan gerakan dasar jalan, dan tidak ada gerakan melompat sama sekali. Uraian di atas dapat dimaknai bahwa latihan senam Low Impact Aerobic membutuhkan daya tahan dan kekuatan. Diutamakan keterampilan gerak dengan merangkai sesuai dengan irama musik, dengan tempo lambat dan cepat, sehingga tercapai keharmonisan gerakan.

Gerakan aerobik mixed impact menunjuk pada gerakan-gerakan dimana tumit mengangkat tetapi jari kaki tetap berada di lantai, kemudian merasa bahwa seolah-olah melompat tetapi sebenarnya tidak (Brick, 2002:33). Latihan senam ini merupakan gabungan dari gerakan lowimpact dan high impact yaitu gabungan yang menggunakan benturan ringan dan benturan tinggi. Pelaksanaan gerakangerakan senam aerobic mixed impact ini diperlukan ada pengulangan gerakan dari latihan itu sendiri. Marandi (2013) senam aerobik dengan benturan menengah berpengaruh terhadap kompoisisi tubuh dan senam aerobik ini lebih berpengaruh terhadap wanita. Selain itu latihan senam aerobik mixed impact ini merupakan kombinasi rangakaian dari gerakan low impact aerobic dengan high impact aerobic, yang mana gerakan kaki suatu saat meninggalkan lantai dan kadang kala tetap berada dilantai sehingga melibatkan berbagai otot.

Berdasarkan uraian tersebut, peneliti tertarik untuk melakukan penelitian tentang "pengaruh latihan senam aerobik low impact dan mixed impact terhadap indeks massa tubuh member senam aerobik Muslimah Fitness Center". Penelitian ini diharapkan dapat menemukan cara latihan yang lebih efektif dan efisien dalam mendapatkan berat badan normal.

\section{METODE}

Penelitian yang akan dilaksanakan menggunakan metode penelitian kuantitatif dengan pendekatan eksperimen semu. Menurut Donald Ary dalam Umar "eksperimen semu (quasi eksperimen) adalah jenis penelitian eksperimen dimana si peneliti tidak dapat mengendalikan secara penuh semua variabel yang kemungkinan dapat berpengaruh terhadap variabel terikat". Bentuk penelitian ini banyak digunakan di bidang ilmu 
pendidikan atau penelitian dengan subjek penelitian yang diteliti adalah manusia, dimana mereka tidak dibedakan antara satu dengan yang lain. (Darmadi, 2011:36). Dengan disain penelitian ini menggunakan rancangan two group pre test post test design.

Pada penelitian ini yang menjadi populasinya yaitu member tetap aktif Muslimah Fitness Center Kota Padang yang berjumlah 25 orang. Untuk menentukan sampel yang akan digunakan dalam penelitian ini yaitu digunakan teknik sampling proportionate stratified random sampling. Kemudian diperoleh 24 sampel. Ke 24 orang sampel ini dibagi menjadi 2 kelompok. Cara pembagian kelompok ini dilakukan secara ordinally matching pairing maksudnya supaya ratarata kemampuan dari 2 kelompok tidak terlalu jauh beda.

Penelitian dilakukan selama 16 kali pertemuan dan 3 kali dalam seminggu. Dilakukan pengambilan data berat badan dan tinggi member, kemudian diklasifikasikan ke dalam IMT ambang batas Indonesia. Setelah itu diberikan perlakuan terhadap member yang telah dibagi menjadi kelompok low impact dan kelompok mixed impact. Setelah dilakukan perlakuan sebanyak 16 kali maka dilakukan pengambilan data yang disebut post test.

\section{HASIL}

\section{Latihan Senam Aerobik Low impact Berpengaruh terhadap Penurunan Indeks Massa Tubuh Member Senam Aerobik Muslimah Fitness Center.}

Hasil tes awal (pre test) indeks massa tubuh member Muslimah Fitness Center senam aerobik low impact dengan jumlah sampel 12 orang diperoleh skor tertinggi 30 skor terendah 23, rata-rata (mean) 26,67 dan simpangnan baku (SD) 2,15. Selanjutnya pada tes akhir (post test) diperoleh skor tertinggi 29,69 dan skor terendah 22,43, rata-rata (mean) 25,69 dan simpangan baku (SD) 2,42. Pada data pre test diperoleh member yang memiliki klasifikasi IMT normal sebanyak 3 orang, klasifikasi gemuk ringan sebanyak 5 orang dan gemuk berat sebanyak 4 orang. Kemudian pada data post test diperoleh member yang termasuk klasifikasi normal meningkat sebanyak 6 orang, termasuk klasifikasi gemuk ringan sebanyak 3 orang dan termasuk klasifikasi gemuk berat menurun menjadi 3 orang. Secara lebih jelas penyebaran distribusi frekuensi pengaruh latihan senam aerobik low impact dapat dilihat pada histogram berikut :

Gambar 1. Pengaruh Latihan Senam aerobik Low impact

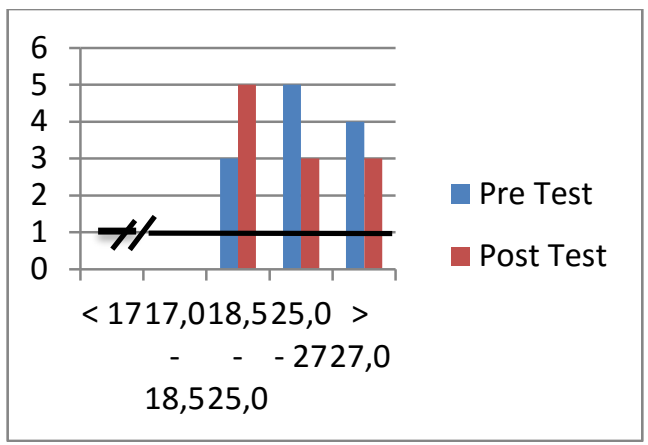

Pengaruh latihan senam aerobik Mixed impact terhadap indeks Massa Tubuh member Muslimah Fitness Center Kota Padang

Hasil tes awal (pre test) indeks massa tubuh member Muslimah Fitness Center senam aerobik mixed impact dengan jumlah sampel 12 orang diperoleh skor tertinggi 33,2 skor terendah 24, rata-rata (mean) 28,25 dan simpangan baku (SD) 2,875. Selanjutnya pada tes akhir (post test) diperoleh skor tertinggi 32,42, skor terendah 23,11, rata-rata (mean) 27,5 dan simpangan baku (SD) 2,75. Pada data pre test kelompok mixed impact diperoleh member yang memiliki klasifikasi IMT normal hanya 1 orang, klasifikasi gemuk ringan sebanyak 3 orang dan gemuk berat sebanyak 8 orang. Kemudian pada data post test diperoleh member yang termasuk klasifikasi normal meningkat sebanyak 3 orang, termasuk klasifikasi gemuk ringan 
sebanyak 3 orang dan termasuk klasifikasi gemuk berat menurun menjadi 6 orang. Untuk lebih jelasnya dapat dilihat pada tabel berikut. Secara lebih jelas penyebaran distribusi frekuensi pengaruh latihan senam aerobik mixed impact dapat dilihat pada histogram berikut :

\section{Gambar 2. Pengaruh Latihan Senam aerobik Mixed impact}

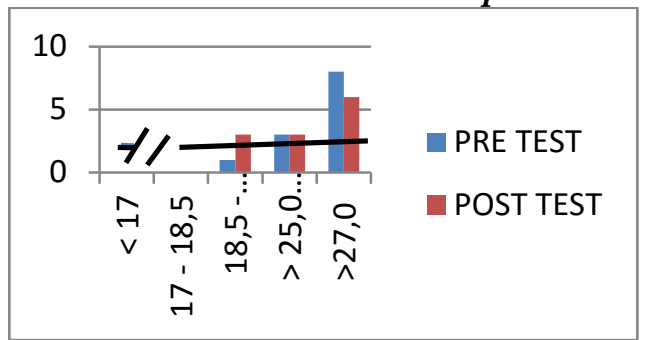

Selisih Pengaruh Latihan Senam AerobikLow impact dengan Mixed impact terhadap Indeks Massa Tubuh

Hasil selisih dari senam aerobik low impact dan mixed impact terhadap indeks massa tubuh dimana hasil yang diperoleh dari senam low impact terhadap indeks massa tubuh dengan jumlah sampel 12 orang diperoleh selisih tertinggi 1,90, skor terendah 0,00, rata-rata (mean) 0,05 dan simpangan baku 0,61. Kemudian pada senam aerobik mixed impact diperoleh hasil selisih tertinggi yaitu dengan skor 2,14 , skor terendah 0,42 , rata-rata (mean) 0,96 dan simpangan baku 0,43.

\section{Uji Persyaratan Analisis}

\section{Uji Normalitas}

Dari hasil pengolahan data uji normalitas dengan uji gallat diperoleh angka normalitas distribusi data seperti pada tabel berikut :

Tabel 2. Rangkuman Hasil Pengujian Normalitas

\begin{tabular}{|c|c|c|c|c|}
\hline Data & $\mathrm{N}$ & Lhitung & $\begin{array}{c}\mathrm{L} \\
\text { tabel }\end{array}$ & Ket \\
\hline $\begin{array}{c}\text { Low } \\
\text { impactPre } \\
\text { test dan } \\
\text { Post test }\end{array}$ & 12 & 0,1808 & 0,242 & Normal \\
\hline $\begin{array}{c}\text { Mixed } \\
\text { impactPre } \\
\text { test dan } \\
\text { Post test }\end{array}$ & 12 & 0,1816 & 0,242 & Normal \\
\hline
\end{tabular}

\begin{tabular}{ccccc}
\hline Data & $\mathrm{N}$ & Lhitung & $\begin{array}{c}\mathrm{L} \\
\text { tabel }\end{array}$ & Ket \\
\hline $\begin{array}{c}\text { Post } \\
\text { testLow }\end{array}$ & & & & \\
$\begin{array}{c}\text { impact } \\
\text { dan }\end{array}$ & 12 & $\mathbf{0 , 1 0 5 4}$ & $\mathbf{0 , 2 4 2}$ & Normal \\
$\begin{array}{c}\text { Mixed } \\
\text { impact }\end{array}$ & & & & \\
\hline
\end{tabular}

Tabel menunjukkan bahwa hasilpengujian normalitas gallat untuk data kelompok senam aerobik low impact pre test dan post test yaitu 0,1808 dengan Ltabel 0,242 dengan $\alpha=0,05$, dengan ketentuan $\mathrm{L}_{\text {tabel }}<\mathrm{L}_{\text {hitung }}$ maka berdistribusi normal maka dapat diartikan bahwa data berdistribusi normal. Hasil pengujian normalitas gallat untuk data kelompok mixed impact pre test dan post test yaitu $\mathrm{L}_{\text {hitung }}=0,1816$ dan $\mathrm{L}_{\text {tabel }}=0,242$ dengan $\alpha$ $=0,05$, dengan ketentusn jika $\mathrm{L}_{\text {hitung }}<\mathrm{L}_{\text {tabel }}$ maka berdistribusi normal maka dapat diartikan bahwa data berdistribusi normal. Kemudian untuk normalitas data post testlow impact dan post testmixed impact diperoleh $\mathrm{L}_{\text {hitung }}=0,1054$ dan $\mathrm{L}_{\text {tabel }}$ 0,242. Dengan ketentuan jika $\mathrm{L}_{\text {hitung }}<\mathrm{L}_{\text {tabel }}$ maka data berdistribusi normal berarti data ini berdistribusi normal.

\section{UJI HOMOGENITAS}

Hasil analisis data diperoleh sebagai berikut :

Tabel 3. Data Low impact dan Mixed impact

\begin{tabular}{ccc}
\hline No & $\mathrm{X}_{1}$ & $\mathrm{X}_{2}$ \\
\hline 1 & 27,39 & 24,44 \\
\hline 2 & 26,56 & 24,61 \\
\hline 3 & 24,77 & 27,34 \\
\hline 4 & 29,69 & 26,67 \\
\hline 5 & 23,34 & 29,90 \\
\hline 6 & 27,73 & 28,40 \\
\hline 7 & 24,34 & 23,11 \\
\hline 8 & 24,56 & 30,84 \\
\hline 9 & 22,43 & 26,14 \\
\hline 10 & 24,69 & 29,04 \\
\hline 11 & 26,67 & 26,56 \\
\hline 12 & 26,14 & 32,42 \\
\hline Jumlah & 308,31 & 329,47 \\
\hline Mean & 25,69 & 27,45 \\
\hline SD & 2,05 & 2,75 \\
\hline Varian & 4,2 & 7,7
\end{tabular}




$$
\begin{gathered}
F \text { hitung }=\frac{\text { Varians terbesar }}{\text { Varians terkecil }} \\
F \text { hitung }=\frac{7,7}{4,2}=1,80
\end{gathered}
$$

Hasil analisis terlihat bahwa nilai $F_{\text {hitung }}$ adalah 1,80 sedangkan $F_{\text {tabel }}$ dengan menggunakan derajat kebebasan (n1-1), (n2-1) dengan taraf siginifikansi $(\alpha)=$ 0,05 , maka diperoleh $\mathrm{F}_{\text {tabel }}=2,82$. Dengan kriteria pengujian jika $F_{\text {hitung }} \geq \mathrm{F}$ tabel dinyatakan tidak homogen, jika $F_{\text {hitung }} \leq \mathrm{F}$ tabel dinyatakan homogen. Dengan demikian data penelitian ini $F_{\text {hitung }}(1,80)$ $\leq \mathrm{F}$ tabel $(2,82)$ adalah homogen, sehingga dapat dilanjutkan untuk analisis pengujian hipotesis.

\section{UJI HIPOTESIS}

Terdapat pengaruh senam aerobik low impact terhadap indeks massa tubuh member Muslimah Fitness Center Kota Padang.

Uji statistik yang digunakan adalah $t$ test yaitu melihat pengaruh rerata hitung dalam satu kelompok yang sama pada taraf signifikan 0,05. Hasil tes awal (pre test) kemampuan latihan senam aerobik low impact dengan jumlah sampel 12 orang diperoleh skor tertinggi 29,69, skor terendah 22,83, rata-rata (mean) 26,33 dan simpangan baku 2,15. Hasil tes akhir (post test) latihan senam aerobik low impact dengan jumlah sampel 12 orang diperoleh skor tertinggi 29,69, skor terendah 22,43, rata-rata (mean) 25,8 dan simpangan baku 2,05. Adapun hasil pengujian hipotesis disajikan dalam tabel berikut.

Tabel 4. Rangkuman Hasil Pengujian Hipotesis Pertama Senam Aerobik Low impact.

\begin{tabular}{|c|c|c|c|c|}
\hline $\begin{array}{c}\text { Sena } \\
\mathrm{m} \\
\text { Aero } \\
\text { bik } \\
\text { Low } \\
\text { impa } \\
\text { ct }\end{array}$ & $\begin{array}{c}M \\
e a \\
n\end{array}$ & $\begin{array}{l}\text { S } \\
\mathrm{D}\end{array}$ & A & Ket \\
\hline $\begin{array}{c}\text { Post } \\
\text { test }\end{array}$ & $\begin{array}{c}25, \\
69\end{array}$ & $\begin{array}{l}2, \\
05\end{array}$ & $\begin{array}{l}0, \\
05\end{array}$ & $\begin{array}{c}\mathrm{Ha} \\
\text { diterim } \\
\mathrm{a}\end{array}$ \\
\hline
\end{tabular}

\begin{tabular}{ccccccc}
\hline Sena & & & & & & \\
$\mathrm{m}$ & & & & & & \\
Aero & $M$ & $\mathrm{~S}$ & $\mathrm{t}_{\text {hit }}$ & & & \\
bik & $e a$ & $\mathrm{D}$ & utabl & Ket \\
$\begin{array}{c}\text { Low } \\
\text { impa }\end{array}$ & $n$ & & & & & \\
ct & & & & & & \\
\hline $\begin{array}{c}\text { Pre } \\
\text { test }\end{array}$ & 26, & 2, & 3, & 0, & 2,07 & Ho \\
\hline
\end{tabular}

Berdasarkan tabel dapat dilihat bahwa $t_{\text {hitung }}(3,64)>t_{\text {tabel }}(2,074)$. Hal ini berarti bahwa hipotesis penelitian diterima. Dengan demikian dapat diartikan bahwa latihan senam aerobik low impact memberikan pengaruh terhadap indeks massa tubuh member Muslimah Fitness Center Kota Padang. Tergambardari selisih antara rata-rata pre test $(26,33)$ dan post test $(25,69)$ dengan perhitungan selisih yaitu 0,64 artinya bahwa senam aerobik low impact memiliki pengaruh terhadap penurunan indeks massa tubuh member Muslimah Fitness Center Kota Padang.

Terdapat Pengaruh Antara Latihan Senam Aerobik Mixed Impact Pada Indeks Massa Tubuh Member Muslimah Fitness Center Kota Padang.

Uji statistik yang digunakan adalah $t$ test yaitu melihat pengaruh rerata hitung dalam satu kelompok yang sama pada taraf signifikan 0,05. Hasil tes awal (pre test) kemampuan latihan senam aerobik mixed impact dengan jumlah sampel 12 orang diperoleh skor tertinggi 33,3, skor terendah 24, rata-rata (mean) 28,25 dan simpangan baku 2,15. Hasil tes akhir (post test) latihan senam aerobik mixed impact dengan jumlah sampel 12 orang diperoleh skor tertinggi 33,42, skor terendah 23,11, rata-rata (mean) 27,5 dan simpangan baku 2,75. Adapun hasil pengujian hipotesis disajikan dalam tabel berikut. 
Tabel 5. Rangkuman Hasil Pengujian Hipotesis Pertama Senam Aerobik Mixed impact.

\begin{tabular}{|c|c|c|c|c|c|c|}
\hline $\begin{array}{c}\text { Senam } \\
\text { Aerobi } \\
\mathrm{k} \\
\text { Mixed } \\
\text { impact }\end{array}$ & $\begin{array}{c}\text { Mea } \\
n\end{array}$ & SD & $\begin{array}{c}\mathrm{t}_{\text {hitun }} \\
\mathrm{g}\end{array}$ & A & $\begin{array}{c}\mathrm{t}_{\text {tabe }} \\
1\end{array}$ & $\begin{array}{c}\text { Kete } \\
\text { rang } \\
\text { an }\end{array}$ \\
\hline Pre test & $\begin{array}{c}28,4 \\
1\end{array}$ & $\begin{array}{l}2,8 \\
75\end{array}$ & \multirow{2}{*}{$\begin{array}{c}3,04 \\
5\end{array}$} & $\begin{array}{c}0, \\
05\end{array}$ & \multirow{2}{*}{$\begin{array}{c}2,0 \\
7\end{array}$} & $\begin{array}{c}\text { Ho } \\
\text { ditol } \\
\text { ak }\end{array}$ \\
\hline $\begin{array}{c}\text { Post } \\
\text { test }\end{array}$ & $\begin{array}{c}27,4 \\
5\end{array}$ & $\begin{array}{c}2,7 \\
5\end{array}$ & & $\begin{array}{c}0, \\
05\end{array}$ & & $\begin{array}{c}\mathrm{Ha} \\
\text { diter } \\
\text { ima }\end{array}$ \\
\hline
\end{tabular}

Berdasarkan tabel dapat dilihat bahwa $t_{\text {hitung }}(3,045)>t_{\text {tabel }}(2,074)$. Hal ini berarti bahwa hipotesis penelitian diterima. Dengan demikian dapat diartikan bahwa latihan senam aerobik mixed impact memberikan pengaruh terhadap indeks massa tubuh member Muslimah Fitness Center Kota Padang. Tergambardari selisih antara rata-rata pre test $(28,25)$ dan post test $(27,5)$ dengan perhitungan selisih yaitu 0,95 artinya bahwa senam aerobik low impact memiliki pengaruh terhadap penurunan indeks massa tubuh member Muslimah Fitness Center Kota Padang.

\section{Latihan Senam Aerobik Mixed Impact} Lebih Berpengaruh Daripada Latihan Senam Aerobik Low Impact Terhadap Indeks Massa Tubuh Member Muslimah Fitness Center Kota Padang.

Uji yang digunakan adalah membandingkan selisih rata-rata post test senam aerobik low impact dengan mixed impact. Untuk senam aerobik low impact dengan rata-rata pada pre test 26,67 dan pada post testyaitu 25,69 diperoleh selisih dari pre test dan post test sebesar 7, 69 rata-rata 0,64 dan rata-rata data mixed impact pre test yaitu 28,25 dan pada post test 27,5 dengan jumlah selisih sebesar 11,44 dan rata-rata selisih 0,96. Dengan demikian bahwa selisih rata-rata low impact $(0,64)<$ rata rata mixed impact $(0,96)$. Kemudian dianalisis menggunakan uji t. Adapun hasil pengujian analisis hipotesis ketiga disajikan dalam tabel berikut.
Tabel 6. Rangkuman Hasil Pengujian Hipotesis Ketiga

\begin{tabular}{|c|c|c|c|c|c|c|}
\hline $\begin{array}{c}\text { Senam } \\
\text { Aerobik }\end{array}$ & $\begin{array}{c}\mathrm{Se} \\
\text { lisi } \\
\mathrm{h}\end{array}$ & $\begin{array}{c}\mathrm{M} \\
\mathrm{ea} \\
\mathrm{n}\end{array}$ & $\begin{array}{l}\mathrm{t}_{\text {hit }} \\
\text { ung }\end{array}$ & A & $\begin{array}{c}\mathrm{t}_{\mathrm{tab}} \\
\mathrm{el}\end{array}$ & Ket \\
\hline $\begin{array}{c}\text { Low } \\
\text { Impact }\end{array}$ & $\begin{array}{l}7, \\
69\end{array}$ & $\begin{array}{l}0, \\
69\end{array}$ & \multirow{2}{*}{$\begin{array}{c}1,6 \\
3\end{array}$} & \multirow{2}{*}{$\begin{array}{l}0, \\
05\end{array}$} & \multirow{2}{*}{$\begin{array}{l}2, \\
07\end{array}$} & $\begin{array}{c}\text { Ho } \\
\text { diteri } \\
\text { ma }\end{array}$ \\
\hline $\begin{array}{l}\text { Mixed } \\
\text { Impact }\end{array}$ & $\begin{array}{l}11 \\
4 \\
4\end{array}$ & $\begin{array}{l}0, \\
95\end{array}$ & & & & $\begin{array}{c}\mathrm{Ha} \\
\text { ditolak }\end{array}$ \\
\hline
\end{tabular}

Berdasarkan tebel dapat dilihat bahwa $t_{\text {hitung }}(1,63)<t_{\text {tabel }}(2,07)$. Hal ini berarti bahwa hipotesis penelitian ditolak. Walaupun tergambar dari selisih terlihat latihan senam aerobik mixed impact memiliki jumlah selisih lebih besar dibandingkan jumlah selisih latihan senam aerobik low impact.

\section{PEMBAHASAN}

Hasil penelitian menunjukkan bahwa metode latihan senam aerobik low impactmenurunkan indeks massa tubuh, namun penurunan yang diharapkan belum maksimal.Terlihat pada kelompok sampel yang melakukan latihan senam aerobik low impact pada pre test terdapat 3 member yang telah memiliki indeks massa tubuh normal dan 9 termasuk klasifikasi gemuk. Dari 9 member ini 5 diantaranya tergolong gemuk ringan dan 4 gemuk berat. Setelah melakukan latihan senam aerobik low impact selama 16 minggu para member memang mengalami penurunan berat badan. Hal ini terlihat pada data post test bahwa member yang termasuk klasifikasi normal meningkat menjadi 6 orang. Walaupun masih terdapat member yang tergolong dalam kategori gemuk berat dan gemuk sedang namun indeks massa tubuh mereka menurun. Hal ini menunjukkan bahwasanya latihan senam aerobik low impact berpengaruh terhadap indeks massa tubuh member. Namun seberapa besar penurunan indeks massa tubuh para member itu banyak faktor yang mempengaruhi seperti jadwal makan 
member yang tidak bisa sepenuhnya peneliti ketahui.

Secara teori senam aerobik adalah aktivitas (gerak) yang dilakukan oleh perorangan maupun kelompok orang secara berirama, menggunakan otot-otot besar, serta aktivitas dilakukan dengan menggunakan oksigen yang bertujuan untuk peningkatan dan pemeliharaan kebugaran (Apri Agus, 2012:5). Senam aerobik memiliki tujuan yaitu meningkatkan kemampuan jantung dan paru dan pembentukan tubuh (Marta Dinata, 2004:5).

Menurut Sumosardjuno (1996:63) latihan senam aerobik memiliki banyak tujuan, low impact ini dianjurkan bagi yang berat badannya berlebih atau juga bagi mereka yang baru mulai melakukan latihan senam aerobik. Lebih lanjut Sumosadjuno mengatakan keuntungan pada badan kita dengan melakukan latihan-latihan senam aerobik terutama pada jantung dan paru serta aktivitas senam aerobik adalah cara klasik untuk membakar lemak.

Berdasarkan pendapat diatas dapat dikemukakan bahwa senam aerobik low impactmerupakan gerak yang bekualitas yang mengandung arti sebagai suatu sistem untuk peningkatan kemampuan fisik yang dilakukan secara teratur, terarah dan kontiniu. Senam aerobik low impact baik diterapkan pada penderita kelebihan berat badan yang memiliki usia lanjut karena latihan yang diterapkan latihan yang menggunakan otot-otot besar dan dalam durasi lebih dari 20 menit sehingga dapat menurunkan berat badan namun dengan risiko cedera yang rendah karena memiliki tingkat benturan yang rendah.

\section{Pengaruh Antara Latihan Senam Aerobik Mixed impact Pada Indeks Massa Tubuh Member Muslimah Fitness Center Kota Padang.}

Pada hasil post test latihan senam aerobik mixed impact terdapat rata-rata indeks massa tubuh member Muslimah Fitness Center Kota Padang yaitu 27,5 dan pada pre test 28,25 dengan selisih 0,96. Hasil penelitian menunjukkan bahwa $t_{\text {hitung }}$ $(3,045)>t_{\text {tabel }}(2,074)$. Hal ini berarti bahwa hipotesis penelitian dapat diterima. Pada kelompok sampel yang melakukan latihan senam aerobik mixed impact pada pre test test terdapat 1 member yang telah memiliki indeks massa tubuh normal dan 11 termasuk klasifikasi gemuk. Dari 11 member ini 3 diantaranya tergolong gemuk ringan dan 8 gemuk berat. Setelah melakukan latihan senam aerobik mixed impact selama 16 minggu para member memang mengalami penurunan berat badan. Hal ini terlihat pada data post test bahwa member yang termasuk klasifikasi normal meningkat dari hanya 1 member menjadi 3 orang, kemudian member yang termasuk klasifikasi gemuk ringan tetap sebanyak 3 orang namun dengan member yang berbeda lalu pada klasifikasi gemuk berat turun menjadi 6 member. Walaupun masih terdapat member yang tergolong dalam kategori gemuk berat dan gemuk sedang namun indeks massa tubuh mereka menurun. Hal ini menunjukkan bahwasanya latihan senam aerobikmixed impact berpengaruh terhadap indeks massa tubuh member.

Namun seberapa besar penurunan indeks massa tubuh para member itu banyak faktor yang mempengaruhi seperti jadwal makan member yang tidak bisa sepenuhnya peneliti ketahui dan juga pada saat pelaksaan latihan para member juga tidak sepenuhnya mekakukan gerakan dengan benar dan tepat. Walaupun member tetap melakukan gerakan senam aerobik namun jika gerakan yang dilakukan tidak sepenuhnya benar maka berpengaruh terhadap hasilnya.

Terjadinya hal ini karena latihan senam aerobik mixed impact melibatkan otot-otot besar dalam tubuh. Serperti menurut Apri Agus (2012:5) senam aerobik adalah aktivitas (gerak) yang dilakukan oleh perorangan maupun kelompok orang secara berirama, menggunakan otot-otot besar, serta aktivitas dilakukan dnegan menggunakan 
oksigen yang bertujuan untuk peningkatan dan pemeliharaan kebugaran.Dikutip dari buletin "Total Fitness Training Centre" bahwa senam aerobik adalah bentuk latihan atau gerakan yang dilakukan berulang-ulang kali menggunakan kumpulan otot-otot besar sekurangkurangnya 15 menit dan membutuhkan oksigen sebagai sumber tenaga.

Gerakan aerobik mixed impact menunjuk pada gerakan-gerakan dimana tumit mengangkat tetapi jari kaki tetap berada dilantai, anda merasa bahwa anda seolah-olah melompat tetapi sebenarnya tidak dalam Brick (2002:33). Keterampilan latihan gerakan senam aerobik mixed impact dipadukan dengan iringan musik yang berguna untuk memberikan dorongan untuk melakukan gerakan senam.

Latihan senam aerobik mixed impact dilaksanakan pada waktu lebih dari 20 menit maka dari itu proses sistem energi dalam tubuh menjadi sistem energi aerobik yang merupakan lemak menjadi bahan bakar sehingga memberikan efek kepada member memberikan pengaruh terhadap indeks massa tubuh.

Senam Aerobik Mixed impact Lebih Berpengaruh Daripada Latihan Senam Aerobik Low impact Terhadap Indeks Massa Tubuh Member Muslimah Fitness Center Kota Padang.

Untuk melihat apakah senam aerobik mixed impact lebih berpengaruh daripada latihan senam aerobik low impact terhadap indeks massa tubuh Member Muslimah Fitness Center Kota Padang dengan melihat selisih rata-rata post test masingmasing dan dilanjutkan dengan uji analisis menggunakan uji t. Berdasarkan selisih rata-rata post test kedua metode latihan diperoleh senam aerobik low impact yaitu 0,64 sedangkan senam aerobik mixed impact yaitu 0,95 .

Pada kedua program latihan memang diketahui terdapat pengaruh atau penurunan indeks massa tubuh pada member Muslimah Fitness Center Kota Padang namun melihat selisih penurunan indeks massa tubuh masing-masing program kemudian dianalisis dengan uji $\mathrm{t}$ diperoleh hasil $\mathrm{t}$ hitung $1.63<\mathrm{t}_{\text {tabel }} 2,074$ yang bermakna tidak terdapat perbedaan signifikan dari kedua program latihan terhadap indeks massa tubuh member Muslimah Fitness Center. Walaupun didapat selisih pada program latihan mixed impact lebih tinggi sehingga daripada latihan senam aerobik low impact terhadap indeks massa tubuh member Muslimah Fitness Center Kota Padang.

Dalam melakukan latihan aerobik dibutuhkan waktu 45-60 menit, karena untuk 20 menit pertama pada kegiatan latihan aerobic tubuh masih menggunakan cadangan gula (glikogen) yang masih tersedia di dalam organ hati dan otot. Jadi latihan dilakukan dalam waktu yang relatif lama.

Pada latihan senam aerobik low impact pada pelaksanaan yang lebih santai tanpa ada paksaan para member dalam menyelesaikan dengan baik maka selama latihan senam aerobik low impact menggunakan sistem energi aerobik dari awal sampai akhir sedangkan pada senam aerobik mixed impact yang memiliki gerakan perpaduan antara high impact dan low impact dalam gerakan terdapat benturan dan memiliki intensitas lebih tinggi dari low impact namun tetap denyut nadi member tetap dalam ambang batas aerobik maka dalam latihan senam aerobiklow impact dan mixed impact energi yang dibentuk tidak jauh berbeda.

\section{KESIMPULAN}

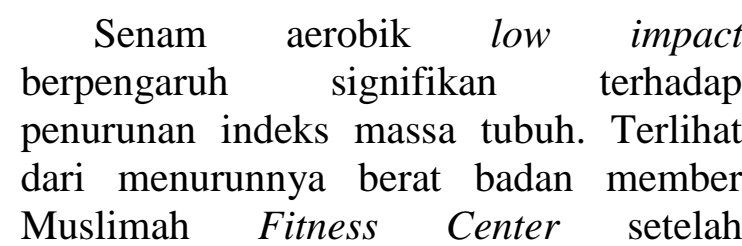
melakukan latihan senam aerobik benturan rendah selama 16 kali. Senam aerobik mixed impact berpengaruh signifikan terhadap penurunan indeks massa tubuh. Dibuktikan dengan menurunnya berat badan member Muslimah Fitness Center 
setelah melakukan latihan senam aerobik kombinasi dari benturan rendah dan tinggi. Setelah dilakukan latihan senam aerobik low impact dan mixed impact diperoleh bahwa kedua latihan ini dapat menurunkan berat badan, namun selisih penurunan berat badan kedua latihan ini tidak jauh berbeda maka dari kedua latihan ini tidak terdapat perbedaan pengaruh terhadap berat badan tubuh member, namun penurunan berat badan member latihan senam aerobik mixed impact lebih besar dibandingkan low impact walau relatif kecil

Penelitian ini diharapkan kepada instruktur untuk memfokuskan gerakan terhadap bagian tubuh yang mudah mengalami penumpukkan lemak yang dapat berakibat peningkatan indeks massa tubuh. Sehingga hasil latihan dapat memberikan motivasi kepada member dalam berlatih dan dapat diduga kepuasan member terhadap indeks massa tubuh tercapai. Kemudian temuan penelitian ini berdampak pada member Muslimah Fitness Center itu sendiri, dimana dalam mengikuti latihan senam menyukai dua bentuk latihan aerobik ini. Selain itu juga dapat disampaikan dari hasil penelitian ini adalah bahwa bentuk latihan senam aerobik low impact dan mixed impact aerobik sama-sama membantu membentuk tubuh ideal dan proposional.

\section{DAFTAR PUSTAKA}

Agus, Apri. 2012. Olahraga Kebugaran Jasmani. Padang: Sukabina Press

Arslan, Fatma. 2011. "The Effects of An Eight-Week Step-Aerobic Dance Exercise Programme on Body Composition Parameters in MiddleAged Sedentary Obese Women". International SportMed Journal, Vol.12 No.4, 2011, pp. 160-168. Available at URL: http://www.ismj.com

Badan Penelitian Pengembangan Kesehatan. 2013. Riset Kesehatan dasar. Jakarta. Departemen Kesehatan.(Online)

Brick, Lynne. 2002. Bugar dengan Senam Aerobik. Jakarta: Raja Grafindo Persada

Darmadi, Hamid. 2011. Metode Penelitian Pendidikan. Bandung. Alfabeta

Departemen Gizi dan Kesehatan Masyarakat. 2010. Gizi dan Kesehatan Masyarakat. Jakarta:Rajawali Press.

Dinata, Marta. 2004. Padat Berisi dengan Aerobik. Jakarta: Cerdas Jaya

Jennifer, Sara Sofia. 2009. "Hubungan Indeks Massa Tubuh dengan Konsentrasi Kolesterol Darah, Trigliserida Darah dan Glukosa Darah Puasa". Online Library UI

Kostic, Radmila, dkk. 2006. "Changes In The Cardiovascular Fitness And Body Composition Of Women Under The Influence Of The Aerobic Dance "Physical Education and Sport Jurnal, Vol. 4, No 1, pp. 59 71

Lutan, Rusli. 2002. Menuju Sehat Bugar. Jakarta. Departemen Pendidikan Nasional

Nourshahi, M, dkk. 2009. "The Effects of triple therapy (acupnture, diet and exercise) on body weight : a randomized, clinical trial)". International Journal of Obesity. Vol 33, page 583-587

Novitasary, Meiriyani Deliana, dkk. 2013. "Hubungan antara Aktivitas Fisik Dengan Obesitas Pada Wanita Usia Subur Peserta Jamkesmas di Puskesmas Wawonasa Kecamatan Singkil Manado". Jurnal e-Biomedik (eBM), Vol 1: No 2

Pitnawati. 2004. Buku Ajar Senam Aerobik. Padang: Fakutas Ilmu Keolahragaan Universitas Negeri Padang

Schiffer, Thorsten, Dkk. 2009. "Effects Of Aerobic Dance And Fitness Programme On Physiological And Psychological Performance In Men 
and Women". International Journal Fitness, Volume 5 No 2 (37-46)

SM, Marandi, dkk. 2013. "Effects Of Intensity Of Aerobics On Body Composition And Blood Lipid Profile In Obese/Overweight Females". International Journal Preventive Medicine; Volume

Sumosardjono, Sadoso. 1996. Sehat dan Bugar. Jakarta: Gramedia Pustaka Utama

Supariasa, dkk. 2001. Penilaian Status Gizi. Jakarta: Buku Kedokteran EGC

Umar. 2013. "Pengaruh Latihan Senam Aerobik Pada Fase Siklus Menstruasi dan Persepsi Terhadap Kapasitas Aerobik Maksimal”. Disertasi tidak diterbitkan. Jakarta. Program Pascasarjana UNJ . 2014. Fisiologi Olahraga. Padang: UNP Press 